\title{
Efektivitas metode problem based learning ditinjau dari kemampuan berpikir kritis dan sikap sosial siswa
}

\author{
Emilia Fatriani ${ }^{\text {a, }}$ 1*, Sukidjo $^{\text {b, } 2}$ \\ ${ }^{a, b}$ Program Studi pendidikan IPS PPs Universitas Negeri Yogyakarta, Sleman, Indonesia \\ ${ }^{1}$ emiliafatriani1991@gmail.com*; , sukidjo@uny.ac.id \\ *korespondensi penulis
}

\begin{tabular}{ll}
\hline Informasi artikel & ABSTRAK \\
\hline Kata kunci: & Penelitian ini bertujuan untuk mendeskripsikan efektivitas metode problem based \\
metode Problem & learning, serta menyelidiki metode manakah yang lebih efektif antara metode Problem \\
based learning; & based learning dan metode ceramah ditinjau dari kemampuan berpikir kritis dan sikap \\
Kemampuan & sosial. Penelitian ini merupakan penelitian eksperimen semu dengan populasi seluruh \\
berpikir kritis; & siswa kelas X MA Nurussalam Tetebatu. Sampel penelitian dipilih secara acak dari tiga \\
sikap sosial & kelas yang ada, sehingga diperoleh kelas X.3 dan X.2. Teknik analisis data terdiri dari: \\
& (1) one sample t-test digunakan untuk menyelidiki perbedaan keefektifan pembelajaran \\
& dengan metode problem based learning, (2) multivariate Analysis of Variance \\
& (Manova) digunakan untuk menyelidiki apakah terdapat perbedaan antara \\
& pembelajaran dengan metode Problem based learning dan metode ceramah, dan (3) uji \\
& lanjut Univariat dengan kriteria Bonferroni digunakan untuk menyelidiki metode mana \\
& yang lebih efektif antara metode Problem Based learning dan metode ceramah ditinjau \\
& dari kemampuan berpikir kritis dan sikap sosial siswa. Hasil penelitian menunjukkan \\
& bahwa (1) pembelajaran dengan metode problem based learning efektif untuk \\
& meningkatkan kemampuan berpikir kritis dan sikap sosial siswa, (2) metode ceramah \\
& tidak efektif untuk meningkatkan kemampuan berpikir kritis siswa, (3) metode ceramah \\
& efektif untuk meningkatkan sikap sosial siswa, dan (4) metode problem based learning \\
& lebih efektif dibandingkan dengan metode ceramah untuk meningkatkan kemampuan \\
& berpikir kritis dan sikap sosial siswa. \\
& ABSTRACT
\end{tabular}

Keywords: problem based learning; critical thinking; social attitude

\begin{abstract}
This study aimed to describe the effectiveness of problem based learning method, and to investigate which method is more effective between problem-based learning method and lecture method in terms of critical thinking skills, and social attitude. This study was a quasi-experimental research with the entire population of tenth grade students of MA Nurussalam Tetebatu. The research samples were randomly selected from the three existing classes, in order to obtain class X.3 and X.2. Data analysis technique consisted of: (1) One sample t-test was used to investigate the effectiveness of problem based learning method, (2) Multivariate Analysis of Variance (Manova) was used to investigate whether there is a difference between problem based learning method and lecture method, and 3) univariate test with Bonferroni criteria, used to investigate which method is more effective between problem based learning method and lecture method in terms of the critical thinking skills, and social attitude. The results show that (1) problem based learning method is effective to increase critical thinking skills, and social attitude of students, (2) the lecture method is not effective to increase critical thinking skills of students, (3) the lecture method is effective to increase social attitude students, and (4) problem based learning method is more effective than lecture method to increase critical thinking skills, and social attitude of students.
\end{abstract}

\section{Copyright ${ }^{\circ} 2018$ Emilia Fatriani dan Sukidjo All Right Reserved}

\section{PENDAHULUAN}

Kemajuan dan perkembangan zaman menuntut adanya perubahan serta perbaikan dalam sistem pendidikan di Indonesia yang disesuaikan dengan kebutuhan masyarakat. Kemajuan zaman yang ditandai dengan perkembangan teknologi dari waktu ke waktu memberikan kemudahan bagi 
masyarakat dalam mengakses informasiinformasi terutama melalui media elektronik. Beberapa lembaga pendidikan di Indonesia juga memanfaatkan kemajuan teknologi tersebut untuk mengenalkan lembaga pendidikan kepada masyarakat, seperti melalui media sosial.

Kemudahan dalam mengakses informasi melalui media elektronik, mengakibatkan banyaknya informasiinformasi yang masih diragukan kebenarannya, karena tidak memiliki sumber yang jelas. Untuk menghadapi situasi ini, seseorang harus memiliki kemampuan berpikir kritis, agar setiap informasi yang dibaca dikritisi terlebih dahulu, dan dicari kebenarannya. Oleh sebab itu, pendidikan di Indonesia dalam proses pembelajarannya harus memiliki tujuan untuk melatih siswa supaya mampu berpikir kritis dan kreatif dalam menerima pelajaran.

Namun kenyataan yang terjadi dalam proses belajar mengajar di sekolah, guru lebih fokus pada bagaimana siswa mencari jawaban yang benar terhadap soal-soal yang diberikan. Hal ini sesuai dengan pendapat Nelson, Palonsky, \& McCarthy (2004, p.253) yang menyatakan bahwa in traditional school, the main purpose is for students to get the "right answers," not to encourage them to engage in critical thinking. Pendapat di atas menyatakan bahwa pada sekolah tradisional, tujuan utamanya adalah bagaimana peserta didik dapat menjawab dengan benar, bukan untuk mendorong peserta didik untuk terlibat dalam pemikiran kritis

Trianto (2009) menyatakan bahwa pengajaran keterampilan berpikir kritis di Indonesia memiliki beberapa kendala, salah satunya adalah dominasinya guru dalam proses pembelajaran dan tidak memberi akses pada siswa untuk berkembang secara mandiri melalui penemuan dan proses berpikirnya. Kondisi seperti itu juga terjadi di MA Nurussalam Tetebatu, berdasarkan hasil wawancara dengan guru di MA Nurussalam pada tanggal 3 Juli 2014, masalah yang dihadapi siswa dalam proses pembelajaran adalah rendahnya kemampuan berpikir kritis siswa dalam menerima informasi dari guru, siswa cenderung bersifat pasif, dan tidak ada kritisi atau tanggapan atas fakta yang disampaikan oleh guru. Hal ini disebabkan karena selama ini proses pembelajaran yang dilakukan hanya berfokus pada bagaimana siswa mampu untuk menjawab soal-soal yang diberikan dengan benar. Selain itu kemampuan siswa untuk menganalisis materi pelajaran yang diberikan oleh guru juga masih rendah.

Ennis (1996, p.166) mendefinisikan berpikir kritis yakni critical thinking is reasonable reflective thinking focused on deciding what to believe or do. Berpikir kritis adalah berpikir reflektif yang beralasan yang berfokus pada memutuskan apa yang harus dipercaya atau dilakukan. 
Penekanannya adalah pada kewajaran, mengidentifikasi sudut pandang, refleksi, dan proses pengambilan keputusan. mengevaluasi bukti yang ditawarkan untuk Definisi ini juga berarti ketika memecahkan mendukung pengakuan. masalah perlu adanya pertimbangan yang

Selain kemampuan berpikir kritis, masuk akal dan reflektif sehingga dapat mengambil keputusan tentang solusi apa yang tepat dan benar yang dapat digunakan untuk menyelesaikan masalah tersebut.

Untuk melihat kemampuan berpikir kritis, seseorang juga memiliki kecenderungan. Ennis (dalam Hassoubah, 2007, p.94) menyatakan bahwa masalah yang dihadapi oleh siswa adalah sikap siswa saat ini yang kurang memperhatikan lingkungan sekitar sebagai sumber belajar, dan kurang memperdulikan orang lain di sekitarnya dalam berkomunikasi, hasilnya sikap sosial siswa kurang baik.

Gerungan (2004, p.161) menyatakan kecenderungan tersebut meliputi: Mencari bahwa sikap sosial dinyatakan dengan carapernyataan yang jelas dari sebuah cara kegiatan yang sama dan berulang-ulang pertanyaan, Mencari alasan, berusaha terhadap objek sosial. Dalam kegiatan mengetahui informasi dengan baik, pembelajaran, metode pendekatan yang memakai sumber yang memiliki kredibilitas digunakan guru dalam menyampaikan dan menyebutkannya, memperhatikan situasi dan kondisi secara keseluruhan, berusaha tetap relevan dengan ide utama, mengingat kepentingan yang asli dan mendasar, mencari alternatif, bersikap dan berpikir terbuka, mengambil posisi ketika ada bukti yang cukup untuk melakukan sesuatu, mencari penjelasan sebanyak mungkin apabila memungkinkan, bersikap secara sistematis dan teratur dengan bagianbagian dan keseluruhan masalah, menentukan kredibilitas suatu sumber, membedakan antara yang relevan dari yang tidak relevan, membedakan fakta dari penilaian, mengidentifikasi dan dan kurangnya perhatian guru dalam mengevaluasi asumsi yang tidak terucapkan, mengembangkan kemampuan berpikir kritis mengidentifikasi bias yang ada, siswa, kurangnya pemahaman guru tentang 
perlunya mengembangkan kemampuan berpikir kritis siswa, rendahnya kemampuan berpikir kritis siswa dalam proses pembelajaran, siswa kurang mampu menganalisis materi pelajaran, serta kurangnya sikap sosial siswa pada aspek sikap tanggungjawab, dan sikap kerja sama antar siswa. Namun dalam penelitian ini peneliti membatasi pada masalah kurangnya kemampuan berpikir kritis siswa, siswa kurang mampu menganalisis materi pelajaran, dan kurangnya sikap sosial siswa pada aspek tanggung jawab dan sikap kerja sama.

Berdasarkan batasan masalah di atas, metode pembelajaran yang direkomendasikan untuk meningkatkan kemampuan berpikir kritis dan sikap sosial siswa adalah metode problem based learning. karena salah satu tujuan dari penerapan metode PBL adalah membantu siswa dalam mengembangkan kemampuan berpikir dan kemampuan pemecahan masalah, dan membantu siswa untuk menjadi siswa yang mandiri. Pernyataan ini juga didukung oleh pendapat Dutch (dalam Taufik, 2009, p.21) problem based learning (PBL) merupakan metode instruksional yang menantang siswa agar belajar untuk belajar, bekerja sama dalam kelompok untuk mencari solusi bagi masalah yang nyata. Masalah ini digunakan untuk meningkatkan rasa keingintahuan serta kemampuan analitis dan inisiatif atas materi pelajaran. Metode problem based learning

(PBL)

mempersiapkan siswa untuk berpikir kritis, dan analisis untuk mencari serta menggunakan sumber pembelajaran sesuai. Wood (2004) menyatakan bahwa: In problem based learning students have to be active: they have to develop a range of skills including being able to work in others, make decisions and reach conclusions, etc all quite different from memorizing information. Makna pernyataan diatas adalah di dalam problem based learning siswa aktif apabila: mereka mengembangkan kemampuan termasuk untuk bekerja sama dalam kelompoknya, merumuskan masalah, menemukan informasi, menjelaskan informasi yang baru kepada orang lain, dan menyimpulkan semuanya sangat berbeda dengan menghafal informasi.

Adapun ciri-ciri problem based learning menurut Arends \& Kilcher (2010, p.326) adalah problem or issues, authentic, investigation and problem solving, interdisciplinary perspectives, small groups collaboration, product, artifacts, exhibitions, and presentations.

Pembelajaran dengan menggunakan metode problem based learning, dimulai dengan sebuah pertanyaan atau sebuah masalah yang penting, dan bermakna bagi siswa. Oleh sebab itu, untuk memberikan kemudahan pada siswa untuk memahami dan mengidentifikasi permasalahan yang 
ditampilkan, guru harus mengaitkan Tahap II yaitu mengorganisasi siswa untuk pembelajaran dengan situasi atau belajar. Pada tahap kedua guru membantu permasalahan yang ada pada kehidupan siswa untuk mendefinisikan dan nyata.

Metode pembelajaran dengan problem based learning di dalamnya terdapat kelompok-kelompok kecil siswa yang bekerja sama memecahkan suatu masalah yang telah disepakati oleh siswa dan guru dengan prosedur pemecahan masalah, dan berpikir kritis. Pada metode problem based learning, pembelajaran dimulai dengan menyajikan permasalahan nyata yang penyelesaiannya membutuhkan kerja sama diantara siswa. Dalam metode pembelajaran ini guru memandu siswa menguraikan rencana pemecahan masalah menjadi tahaptahap kegiatan, guru memberi contoh mengenai penggunaan keterampilan dan strategi yang dibutuhkan supaya tugas-tugas tersebut dapat diselesaikan. Guru menciptakan suasana kelas yang fleksibel dan berorientasi pada upaya penyelidikan oleh siswa.

Adapun langkah-langkah atau sintaks pembelajaran berbasis masalah (PBL) menurut Suprihatiningrum, (2013, p.223) yaitu tahap I yaitu orientasi pada masalah. Dalam tahap ini guru menjelaskan tujuan pembelajaran, menjelaskan logistik yang dibutuhkan, mengajukan fenomena, demonstrasi atau cerita untuk memunculkan masalah, memotivasi siswa untuk terlibat dalam pemecahan masalah yang dipilih. mengorganisasikan tugas belajar yang berhubungan dengan masalah yang akan dibahas. Tahap III yaitu membimbing penyelidikan individual maupun kelompok. Pada tahap ketiga guru mendorong siswa untuk mengumpulkan informasi yang sesuai, melaksanakan eksperimen, untuk mendapatkan penjelasan dan pemecahan masalah. Tahap IV yaitu mengembangkan dan menyajikan hasil karya. Tahap keempat guru membantu siswa dalam merencanakan dan menyiapkan karya yang sesuai. Seperti laporan, video, dan model serta membantu siswa untuk berbagi tugas dengan temantemannya. Tahap V yaitu menganalisis dan mengevaluasi proses pemecahan masalah. Pada tahap akhir ini guru membantu siswa untuk melaksanakan refleksi/evaluasi terhadap penyelidikan mereka dan prosesproses yang mereka gunakan.

Adapun keuntungan atau kelebihan dari metode problem based learning menurut Westwood (2008, p.31) adalah sebagai encourages self-direction in learning, Prepares students to think critically and analytically, Empowers students to identify, locate and use appropriate resources, Issues studied are linked closely with the real world and are motivating for students, Active involvement in integrating information and skills from different disciplines, Knowledge 
and strategies acquired are likely to be retained and transferred to other learning situations, and Enhances communication skills and social skills necessary for cooperation and team work.

Sedangkan kelemahan dari model pembelajaran berbasis masalah (PBL) menurut Sanjaya (2009, p.221) adalah sebagai berikut: Manakala siswa tidak memiliki minat atau tidak mempunyai kepercayaan bahwa masalah yang dipelajari sulit untuk dipecahkan, maka mereka akan merasa enggan untuk mencoba. Keberhasilan model strategi pembelajaran melalui problem solving membutuhkan cukup waktu untuk dipecahkan. Tanpa pemahaman mengapa siswa berusaha untuk memecahkan masalah yang dipelajari, maka siswa tidak akan belajar apa yang mereka ingin pelajari.

Penelitian ini bertujuan untuk mendeskripsikan efektivitas metode problem based learning ditinjau dari kemampuan berpikir kritis dan sikap sosial siswa, mendeskripsikan efektivitas metode ceramah ditinjau dari kemampuan berpikir kritis dan sikap sosial siswa, dan mendeskripsikan metode manakah yang lebih efektif antara metode problem based learning dan metode ceramah untuk meningkatkan kemampuan berpikir kritis dan sikap sosial.

Adapun hipotesis yang diuji dalam penelitian ini adalah:
$\mathrm{H}_{0}=$ Pembelajaran menggunakan metode problem based learning tidak efektif ditinjau dari kemampuan berpikir kritis siswa $(\mu<75)$

$\mathrm{H}_{1}=$ Pembelajaran menggunakan metode problem based learning efektif ditinjau dari kemampuan berpikir kritis siswa $(\mu>75)$

$\mathrm{H}_{0}=$ Pembelajaran menggunakan metode problem based learning tidak efektif ditinjau dari sikap sosial siswa. $(\mu<120)$

$\mathrm{H}_{1}=$ Pembelajaran menggunakan metode problem based learning efektif ditinjau dari sikap sosial siswa $(\mu>$ 120)

$\mathrm{H}_{0}=$ Pembelajaran menggunakan metode ceramah tidak efektif ditinjau dari kemampuan berpikir kritis siswa $(\mu<75)$

$\mathrm{H}_{1}=$ Pembelajaran menggunakan metode ceramah efektif ditinjau dari kemampuan berpikir kritis siswa $(\mu>$ 75)

$\mathrm{H}_{0}=$ Pembelajaran menggunakan metode ceramah tidak efektif ditinjau dari sikap sosial siswa. $(\mu<120)$

$\mathrm{H}_{1}=$ Pembelajaran menggunakan metode ceramah efektif ditinjau dari sikap sosial siswa $(\mu>120)$.

$\mathrm{H}_{0}=$ Metode problem based learning tidak lebih efektif dibandingkan dengan metode ditinjau dari kemampuan berpikir kritis siswa. 
$\mathrm{H}_{\mathrm{a}}=$ metode problem based learning lebih efektif dibandingkan dengan metode ceramah ditinjau dari kemampuan berpikir kritis siswa.

$\mathrm{H}_{0}=$ Metode problem based learning tidak lebih efektif dibandingkan dengan metode ditinjau dari sikap sosial siswa. $\mathrm{H}_{\mathrm{a}}=$ metode problem based learning lebih efektif dibandingkan dengan metode ceramah ditinjau dari sikap sosial siswa.

\section{METODE}

Jenis penelitian ini adalah penelitian kuantitatif dengan pendekatan eksperimen semu (quasi experiment), dengan desain pretest-postest nonequivalent control group design. Dalam penelitian ini akan dilihat keefektifan suatu metode pembelajaran yaitu metode Problem based learning. Subjek penelitian yang digunakan dalam penelitian ini adalah dua kelompok. Satu kelompok dijadikan sebagai kelas eksperimen, dan satu kelompok dijadikan sebagai kelas kontrol. Adapun kelas eksperimen diberikan perlakuan (treatment) dengan menggunakan metode problem based learning dan kelas kontrol dengan menggunakan metode yang biasa digunakan oleh guru dalam mengajar sehari-hari yaitu ceramah.

Penelitian ini dilaksanakan di kelas X2, dan X3 Madrasah Aliyah Nurussalam Tetebatu, Kecamatan Sikur, Kabupaten Lombok Timur, Provinsi Nusa Tenggara Barat (NTB). Adapun waktu penelitiannya direncanakan berlangsung pada bulan April sampai dengan bulan Mei 2015.

Dari tiga kelas yang ada dipilih satu kelas untuk dijadikan kelas eksperimen dan satu kelas kontrol dari sekolah yang akan diteliti. Berdasarkan hasil random yang dilakukan didapatkan kelas X3 sebagai kelas eksperimen dengan jumlah siswa lakilaki 16 dan perempuan 21 jadi jumlah siswa X3 adalah 37. Sedangkan kelas X2 sebagai kelas kontrol dengan jumlah siswa laki-laki 9 dan perempuan 25 jadi jumlah siswa X2 adalah 34 siswa. Jumlah sampel keseluruhan yang digunakan dalam penelitian ini adalah sebanyak 71 siswa.

Teknik pengumpulan data merupakan alat atau fasilitas yang digunakan oleh peneliti dalam mengumpulkan data agar pekerjaannya lebih mudah dan hasilnya lebih baik dalam arti cermat, lengkap, dan sistematis sehingga mudah diolah. Dalam penelitian ini teknik pengumpulan data yang digunakan adalah teknik tes dengan item pilihan ganda berupa data pre-test dan data post-test. Tes ini digunakan untuk mengukur kemampuan berpikir kritis siswa dalam pembelajaran ekonomi pada materi uang dan perbankan. Sedangkan teknik non tes berupa instrumen angket digunakan untuk mengukur sikap sosial siswa pada kelas eksperimen maupun pada kelas kontrol.

Instrumen pengumpulan data yang digunakan dalam penelitian ini adalah instrumen tes untuk mengukur kemampuan 
berpikir kritis siswa pada mata pelajaran ekonomi materi uang dan perbankan. Tes kemampuan berpikir kritis berupa tes pilihan ganda. Menurut Sukardi (2011, p.117) item tes objektif dikatakan lebih efektif penggunaannya dalam mengukur beberapa hasil belajar siswa. karena dengan penggunaan tes objektif tipe pilihan bisa mengungkapkan materi pembelajaran yang lebih luas. Sedangkan instrumen angket digunakan untuk mengukur sikap sosial siswa baik pada kelas eksperimen maupun pada kelas kontrol.

Validitas yang digunakan dalam penelitian ini terdiri dari dua jenis validitas, yaitu validitas rasional dan validitas empiris. Validitas rasional yaitu validitas isi dengan meminta pertimbangan dari ahli (expert judgement) dalam hal ini adalah pertimbangan dari dosen Pascasarjana UNY, dan validitas konstruk. Validitas konstruk menurut Surapranata (2006, p.53) Mengandung arti bahwa suatu alat ukur dikatakan valid apabila telah cocok dengan konstruksi teoretis dimana tes itu dibuat. Dalam penelitian ini validitas konstruk di estimasi dengan menggunakan analisis faktor. Sedangkan validitas empiris berupa uji coba instrumen di lapangan.

Setelah melakukan validasi terhadap suatu instrumen, selanjutnya adalah menghitung reliabilitas instrumen. Reliabilitas diartikan sama dengan konsistensi atau keajekan. Menurut Sukardi
(2011, p.43) Suatu instrumen dikatakan mempunyai reliabilitas tinggi, apabila tes yang dibuat mempunyai hasil yang konsisten dalam mengukur yang hendak diukur. setelah dilakukan analisis dengan Alpha Cronbach's terhadap tes kemampuan berpikir kritis yang diujicobakan pada kelas XI.1 dan kelas XI.2 didapatkan reliabilitas instrumen adalah 0,663.

Teknik analisis data meliputi analisis deskriptif uji statistik. Teknik analisis deskriptif digunakan untuk mendeskripsikan data untuk semua variabel penelitian. Analisis deskriptif digunakan untuk menyajikan data yang diperoleh melalui angket dan tes dari hasil pre-test dan posttest, baik pada kelas eksperimen maupun kelas kontrol. Analisis deskriptif untuk kemampuan berpikir kritis dan sikap sosial siswa adalah rata-rata, skor maksimal, skor minimal, standar deviasi data yang diperoleh kemudian diinterpretasi ke dalam kriteriakriteria yang telah ditetapkan dan ditentukan persentasenya.

Sedangkan uji statistik digunakan untuk mengambil kesimpulan berdasarkan data yang diperoleh pada saat penelitian, uji statistik ini terdiri dari uji asumsi dan uji hipotesis, adapun hipotesis yang di uji adalah uji keefektifan metode problem based learning dan metode ceramah ditinjau dari kemampuan berpikir kritis dan sikap sosial, kemudian menguji metode manakah yang lebih efektif antara metode problem based 
learning dan metode ceramah untuk rata skor siswa yaitu 120 (berada pada meningkatkan kemampuan berpikir kritis kriteria tinggi).

dan sikap sosial siswa.

Sebelum dilakukan analisis terhadap keefektifan metode problem based learning dan metode ceramah, dengan melihat level penguasaan yang dicapai oleh siswa untuk setiap tujuan pembelajaran dan skor rata-rata pencapaian tujuan-tujuan pembelajaran oleh semua siswa setelah diberikan treatment dengan metode problem based learning. Batas penguasaan standar keberhasilan yang digunakan dalam penelitian ini adalah untuk kemampuan berpikir kritis dikatakan efektif apabila nilai rata-rata kelas mencapai angka $>75 \%$.. Hal ini disesuaikan dengan pendapat Mardapi (2008, p.137) batas penguasaan standar keberhasilan adalah $75 \%$ dan kriteria keefektifan metode pembelajaran Menurut Kemp, Morrison, \& Ross (1994, p.289), indeks keefektifan adalah persentase yang menjelaskan: level penguasaan yang dicapai oleh siswa untuk tiap tujuan pembelajaran, dan rata-rata pencapaian tujuan-tujuan oleh semua siswa. Persentase penguasaan ini ditentukan oleh guru sebelum melaksanakan pembelajaran.

Metode pembelajaran dikatakan efektif apabila ditinjau dari kemampuan berpikir kritis apabila rata-rata skor kemampuan berpikir kritis siswa yaitu 75. Sementara itu, suatu metode pembelajaran dikatakan efektif ditinjau dari sikap sosial siswa apabila rata-
Sebelum melakukan uji hipotesis, datadata yang diperoleh dari penelitian harus memenuhi uji asumsi terlebih dahulu, yaitu uji asumsi normalitas dan uji asumsi homogenitas. Pengecekan asumsi normalitas multivariate dilakukan menggunakan jarak Mahalanobis dengan menggunakan kriteria Chi square $\chi^{2}$ yaitu persentase nilai $d_{i}{ }^{2}<$ $\chi_{p}^{2}(0,5)$ mendekati $50 \%$ maka dapat dikatakan bahwa populasi tersebut berdistribusi normal multivariat Adapun asumsi homogenitas matriks kovarian menggunakan uji Box-M. dengan kriteria Ho ditolak apabila nilai signifikansi lebih kecil dari 0,05. Jika semua uji asumsi terpenuhi, maka dilanjutkan dengan menguji keefektifan kedua metode ditinjau dari masing-masing variable yang dianalisis dengan menggunakan uji-t One sample $t$ test, dengan kriteria $\mathrm{H}_{\mathrm{o}}$ ditolak apabila nilai probabilitas lebih kecil dari taraf signifikansi 0,05 .

Analisis selanjutnya adalah dengan menggunakan uji multivariat T-Hottelling's treace untuk menguji perbedaan keefektifan kedua metode dengan kriteria $\mathrm{H}_{0}$ ditolak apabila nilai probabilitas yang diperoleh lebih kecil dari taraf signifikansi 0,05. Setelah diuji dan diperoleh hasil bahwa terdapat perbedaan keefektifan antara kedua metode, maka dilakukan uji lanjut dengan menggunakan uji univariat dengan 
menggunakan kriteria Bonferroni. Uji lanjut digunakan untuk menyelidiki metode mana yang lebih efektif antara metode problem based learning dan metode ceramah dalam meningkatkan kemampuan berpikir kritis dan sikap sosial siswa.

\section{HASIL DAN PEMBAHASAN}

\section{Hasil Penelitian}

Hasil penelitian terdiri atas hasil uji keefektifan metode problem based learning dan metode ceramah, serta hasill uji metode yang lebih efektif antara metode problem based learning ditinjau dari kemampuan berpikir kritis dan sikap sosial siswa. Namun, sebelum melihat hasil uji hipotesis terlebih dulu melihat hasil uji asumsi. Adapun hasil uji asumsi normalitas multivariat dapat dilihat pada tabel 1 berikut:

Tabel 1. Hasil Uji Normalitas Multivariat

\begin{tabular}{ccc}
\hline Kelompok & $\begin{array}{c}\boldsymbol{d}_{\boldsymbol{i}}^{2} \text { Sebelum } \\
\text { Perlakuan }\end{array}$ & $\begin{array}{c}\boldsymbol{d}_{\boldsymbol{i}}^{2} \text { Setelah } \\
\text { Perlakuan }\end{array}$ \\
\hline $\begin{array}{c}\text { Metode } \\
\text { problem } \\
\text { based } \\
\text { learning } \\
\text { Metode } \\
\text { ceramah }\end{array}$ & $53,33 \%$ & $53,33 \%$ \\
\hline
\end{tabular}

Berdasarkan tabel 1, diperoleh informasi bahwa persentase nilai $d_{i}^{2}<$ $\chi_{3}^{2}(0,5)$ untuk kelompok eksperimen dengan metode problem based learning dan kelompok control dengan metode ceamah sebelum dan setelah perlakuan mendekati $50 \%$ maka dapat dikatakan bahwa sampel berasal dari populasi yang berdistribusi normal multivariat. Adapun untuk hasil uji asumsi homogenitas matriks kovarians dapat dilihat pada Tabel 1berikut:

Tabel 2. Hasil uji homgenitas matrik kovarians

Sebelum Setelah

Perlakuan Perlakuan

\begin{tabular}{ccc}
\hline Box's $M$ & 2,297 & 3,068 \\
$F$ & .734 & .980 \\
Sig. & 0,532 & 0,401
\end{tabular}

Berdasarkan tabel di atas, diperoleh signifikansi 0,532>0,05, maka dapat disimpulkan bahwa variansi data pre-test untuk kedua kelompok adalah sama atau homogen. Hal ini berarti kelompok eksperimen dengan metode problem based learning dan kelompok kontrol dengan metode ceramah mempunyai varians kovarians yang sama untuk data sebelum perlakuan.

Sedangkan untuk data post-test atau data setelah perlakuan berdasarkan tabel di atas, diperoleh taraf signifikansi untuk data post-test adalah 0,401>0,05, maka dapat disimpulkan bahwa variansi data untuk kedua kelompok adalah homogen. Hasil tersebut menunjukkan bahwa kelompok eksperimen dengan metode problem based learning dan kelompok kontrol dengan metode ceramah mempunyai varians kovarians yang sama.

Berdasarkan hasil uji asumsi, terlihat bahwa semua asumsi normalitas dan homogenitas multivariat terpenuhi. Oleh karena itu dapat dilakukan uji keefektifan 
kedua pembelajaran dan uji perbedaan diterima, atau dengan kata lain pembelajaran keefektifan pembelajaran. Hasil uji dengan metode ceramah tidak efektif keefektifan dengan menggunakan One ditinjau dari kemampuan berpikir kritis Sample two tailed $t$ - test, disajikan pada siswa. Untuk sikap sosial dengan metode Tabel 3 sebagai berikut:

Tabel 3. Hasil uji keefektifan metode problem based learning dan metrode ceramah

\begin{tabular}{llc}
\hline Metode & Variabel & $\begin{array}{c}\text { Sig. } \\
2- \\
\text { tailed }\end{array}$ \\
\hline Metode & Kemampuan & 0,006 \\
Problem & berpikir & \\
based & kritis & \\
learning & &
\end{tabular}

\begin{tabular}{lll}
$\begin{array}{lll}\text { Metode } \\
\text { ceramah }\end{array}$ & Sikap sosial & 0,000 \\
& $\begin{array}{l}\text { Kemampuan } \\
\text { berpikir }\end{array}$ & 0,973 \\
& kritis & \\
& Sikap sosial & 0,000 \\
\hline
\end{tabular}

Berdasarkan tabel di atas diperoleh informasi bahwa nilai signifikansi untuk kemampuan berpikir kritis $=0,006<0.05$. Artinya nilai probabilitas lebih kecil dari tarag signifikan 0,05 , hal ini berarti Ho ditolak, atau dengan kata lain pembelajaran dengan metode problem based learning efektif ditinjau dari kemampuan berpikir kritis siswa, dan untuk sikap sosial berdasarkan tabel di atas diperoleh informasi bahwa nilai signifikansi untuk sikap sosial $=$ $0,000<0.05$. Artinya Ho ditolak, atau dengan kata lain pembelajaran dengan metode problem based learning efektif ditinjau dari sikap sosial siswa.

Sedangkan untuk metode ceramah diperoleh hasil 0,973>0,05. Artinya Ho ceramah diperoleh hasil yaitu $0,000<0.05$. Artinya Ho ditolak, atau dengan kata lain pembelajaran dengan metode ceramah efektif ditinjau dari sikap sosial siswa.

Uji hipotesis selanjutnya dilakukan untuk menguji apakah terdapat perbedaan keefektifan antara metode problem based learning dan metode ceramah.

Sebelum menguji hipotesis dalam penelitian ini, terlebih dahulu menyelidiki perbedaan kemampuan berpikir kritis dan sikap sosial siswa pada pre-test atau kemampuan awal siswa untuk kedua kelompok dengan uji multivariat. Uji multivariat yang digunakan adalah uji $T$ hottelling's treace, Dengan hipotesis yang di uji adalah:

$\mathrm{H}_{0}$ : tidak terdapat perbedaan rata-rata kemampuan berpikir kritis dan sikap sosial siswa dengan metode problem based learning dan metode ceramah dalam pembelajaran ekonomi.

$\mathrm{H}_{\mathrm{a}}$ : terdapat perbedaan rata-rata kemampuan berpikir kritis dan sikap sosial siswa dengan metode problem based learning dan metode ceramah dalam pembelajaran ekonomi.

Hasil perhitungan menunjukkan bahwa nilai signifikansi untuk data sebelum pelakuan adalah sebesar 0,108 lebih besar 
dari taraf signifikansi 0,05 . Artinya Hipotesis nol diterima. Dengan kata lain kondisi awal kedua kelompok sama. Jika kondisi awal kedua kelompok sama data setelah perlakuan juga dianalisis menggunakan Multivariate Analysis of Variance (MANOVA) $T^{2}$ Hotelling. Hasil perhitungan menunjukkan bahwa nilai signifikansi yang diperoleh sebesar 0,028 lebih kecil dari taraf signifikansi 0,05. Artinya Hipotesis nol diterima. Dengan demikian terdapat perbedaan antara kedua kelompok.

Oleh sebab itu untuk melihat metode mana yang lebih efektif antara metode problem based learning dan metode ceramah dilakukan uji lanjut dengan menggunakan uji univariat dengan kriteria bonferroni. Adapun hasil uji lanjut dengan uji univariat sebagai berikut:

Tabel 4. Hasil Uji Homogenitas

\begin{tabular}{ccc} 
& Varians & \\
\hline & $\begin{array}{c}\text { Kemampuan } \\
\text { berpikir } \\
\text { kritis }\end{array}$ & $\begin{array}{c}\text { Sikap } \\
\text { sosial }\end{array}$ \\
\hline$F$ & 0,01 & 0,461
\end{tabular}

Statistics)

Sig. 0,980

0,500

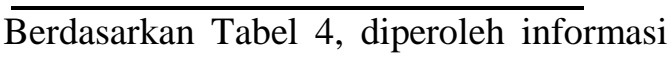
bahwa nilai signifikansi uji Lavene Statistics untuk kedua variabel adalah 0,980; dan 0,500 > 0,05 maka varians kedua kelompok sama (asumsi homogenitas varians terpenuhi).

Setelah uji asumsi homogenitas terpenuhi, selanjutnya menguji metode mana yang lebih efektif dari kedua metode, adapun hasil uji hipotesisnya adalah sebagai berikut:

Tabel 5. Hasil uji-t Independent sample t-test

\begin{tabular}{llc}
\hline Metode & Variabel & $\begin{array}{c}\text { Sig. } \\
\mathbf{2 -} \\
\text { tailed }\end{array}$ \\
\hline Metode & Kemampuan & \\
Problem & berpikir & 0,043 \\
based & kritis & \\
learning & &
\end{tabular}

\begin{tabular}{lll}
$\begin{array}{l}\text { Metode } \\
\text { ceramah }\end{array}$ & Sikap sosial & 0,015 \\
& $\begin{array}{l}\text { Kemampuan } \\
\text { berpikir } \\
\text { kritis }\end{array}$ & 0,048 \\
& Sikap sosial & 0,013 \\
\hline
\end{tabular}

Berdasarkan tabel di atas, diperoleh nilai signifikansi $0,043<0,05$. Hal ini berarti bahwa $\mathrm{H}_{0}$ ditolak atau dengan kata lain, metode problem based learning lebih efektif untuk meningkatkan kemampuan berpikir kritis dibandingkan dengan metode ceramah.

Sedangkan untuk sikap sosial diperoleh nilai signifikansi $0,015<0,05$, maka $\mathrm{H}_{0}$ ditolak. Artinya bahwa metode problem based learning lebih efektif dibandingkan dengan metode ceramah ditinjau dari sikap sosial siswa.

\section{Pembahasan}

Dalam penelitian ini, terdapat enam hipotesis penelitian. Berdasarkan hasil uji analisis keenam hipotesis terpenuhi yaitu: (1) metode problem based learning efektif ditinjau dari kemampuan berpikir kritis siswa, (2) metode problem based learning efektif ditinjau dari sikap sosial siswa pada mata pelajaran ekonomi di MA Nurussalam 
Tetebatu, (3) metode ceramah tidak efektif ditinjau dari kemampuan berpikir kritis siswa pada mata pelajaran ekonomi, (4) metode ceramah efektif ditinjau dari sikap sosial siswa pada mata pelajaran ekonomi, dan (5) metode problem based learning lebih efektif dibandingkan metode ceramah ditinjau dari kemampuan berpikir kritis, dan (6) metode problem based learning lebih efektif dibandingkan metode ceramah ditinjau dari sikap sosial siswa pada pembelajaran ekonomi di MA Nurussalam Tetebatu.

Berdasarkan hasil uji hipotesis di atas didapatkan hasil metode problem based learning efektif untuk meningkatkan kemampuan berpikir kritis dan sikap sosial siswa pada mata pelajaran ekonomi di MA Nurussalam Tetebatu. Hal ini disebabkan pada pembelajaran dengan metode problem based learning siswa lebih aktif dalam mencari solusi-solusi atas permasalahan yang diberikan oleh guru pada saat pembelajaran dimulai. Pembelajaran dengan metode problem based learning juga memberikan kesempatan pada semua siswa untuk berpartisipasi dalam pembelajaran, baik itu pada saat bekerja kelompok, dan mengemukakan hasil diskusi dengan teman kelompoknya di depan kelas.

Sedangkan hasil hipotesis selanjutnya yang menyatakan bahwa metode ceramah tidak efektif untuk meningkatkan kemampuan berpikir kritis siswa, hal ini disebabkan karena pada pembelajaran dengan metode ceramah kegiatan siswa didominasi oleh guru dan aktivitas siswa kebanyakan hanya mendengarkan penjelasan dan mencatat materi pelajaran.

Berdasarkan uji hipotesis pertama, diperoleh hasil bahwa metode problem based learning efektif ditinjau dari kemampuan berpikir kritis dan sikap sosial, sedangkan untuk metode ceramah hanya efektif ditinjau dari sikap sosial siswa. Setelah menguji keefektifan dari kedua metode tersebut, kemudian akan diuji metode manakah yang lebih efektif antara metode problem based learning dan metode ceramah. Namun sebelumnya harus dilakukan uji beda terlebih dahulu dengan uji multivariat T-Hottelling Treace, pada data sebelum perlakuan (pre-tes) diperoleh hasil yaitu $0,108>0,05$. Hal ini berarti bahwa tidak ada perbedaan rata-rata antara kelompok eksperimen yang menggunakan metode problem based learning dengan kelompok kontrol yang menggunakan metode ceramah. Untuk data setelah perlakuan juga dianalisis dengan cara yang sama, dan diperoleh hasil $0,028<0,05$. Hal ini berarti bahwa terdapat perbedaan ratarata antara kelompok eksperimen yang menggunakan metode problem based learning dengan kelompok kontrol yang menggunakan metode ceramah.

Berdasarkan hasil uji multivariat pada data setelah perlakuan diperoleh hasil bahwa 
terdapat perbedaan pada data setelah perlakuan, maka dilakukan uji lanjut dengan menggunakan uji lanjut univariat dengan kriteria Bonferroni. Hasil uji lanjut dengan uji univariat untuk kemampuan berpikir kritis diperoleh nilai $\mathrm{t}=2.071$ dengan taraf signifikansi $0,043<0,05$. Hal ini berarti bahwa metode problem based learning lebih efektif dibandingkan dengan metode ceramah untuk meningkatkan kemampuan berpikir kritis siswa. Kemudian untuk data sikap sosial diperoleh nilai $\mathrm{t}=2,526$ dengan taraf signifikan $0,015<0,05$. Berdasarkan hasil hipotesis dan uji lanjut univariat dengan kriteria Bonferroni di atas, dapat disimpulkan bahwa pembelajaran dengan metode problem based learning lebih efektif untuk meningkatkan kemampuan berpikir kritis dan sikap sosial siswa pada mata pelajaran ekonomi dibandingkan dengan metode ceramah.

Hasil penelitian ini sesuai dengan hasil penelitian yang dilakukan oleh Ismaimuza (2010) yaitu Kemampuan berpikir kritis matematis siswa yang memperoleh pembelajaran problem based learning lebih baik daripada siswa yang memperoleh pembelajaran konvensional, dan sikap siswa yang diajar dengan metode problem based learning lebih positif dibandingkan dengan sikap siswa yang diajar menggunakan metode konvensional.

Selain penelitian di atas, penelitian yang dilakukan oleh Sulaiman dan Eldy (2014) hasil penelitiannya menunjukkan bahwa siswa mampu mengembangkan kemampuan berpikir kritis mereka ketika pembelajaran terintegrasi dengan problem based learning. Hal ini berarti bahwa pembelajaran dengan metode problem based learning efektif untuk mengembangkan kemampuan berpikir kritis siswa.

Selain beberapa hasil penelitian di atas, hasil penelitian ini juga didukung oleh pendapat Dutch (Taufik, 2009, p.21) PBL merupakan metode instruksional yang menantang siswa agar belajar untuk belajar, bekerja sama dalam kelompok untuk mencari solusi bagi masalah yang nyata, masalah ini digunakan untuk meningkatkan rasa keingintahuan serta kemampuan analitis dan inisiatif atas materi pelajaran. PBL mempersiapkan siswa untuk berpikir kritis dan analisis dan untuk mencari dan menggunakan sumber pembelajaran yang sesuai.

Penelitian yang dilakukan oleh Murwantono \& Sukidjo (2015) dengan judul "peningkatan hasil belajar IPS dengan model problem based learning berbantuan media simultan gambar" hasil penelitian menunjukkan bahwa: penerapan model pembelajaran problem based learning berbantuan media stimulan gambar dapat meningkatkan sikap sosial peserta didik terhadap pembelajaran IPS.

Berdasarkan hasil penelitian di atas, maka dapat dibuat suatu rekomendasi bahwa 
untuk mengetahui kemampuan berpikir kritis dan sikap sosial siswa, guru dapat melakukan inovasi pembelajaran dengan menerapkan metode problem based learning dimana pembelajaran berpusat pada siswa yang memberikan pengalaman belajar kepada siswa.

\section{SIMPULAN}

Pembelajaran dengan menggunakan metode problem based learning efektif untuk meningkatkan kemampuan berpikir kritis siswa pada mata pelajaran ekonomi di MA Nurussalam Tetebatu. Pembelajaran dengan menggunakan metode problem based learning efektif untuk meningkatkan sikap sosial siswa pada mata pelajaran ekonomi. Pembelajaran dengan menggunakan metode ceramah tidak efektif untuk meningkatkan kemampuan berpikir kritis siswa pada mata pelajaran ekonomi. Pembelajaran dengan menggunakan metode ceramah efektif untuk meningkatkan sikap sosial siswa pada mata pelajaran ekonomi. Pembelajaran dengan Metode problem based learning lebih efektif untuk meningkatkan kemampuan berpikir kritis siswa pada mata pelajaran ekonomi. Pembelajaran dengan Metode problem based learning lebih efektif untuk meningkatkan sikap sosial siswa dibandingkan pembelajaran dengan menggunakan metode ceramah pada mata pelajaran ekonomi

\section{DAFTAR PUSTAKA}

Arends, R.I \& Kilcher, A. (2010). Teaching for students learning becoming an accomplished teacher. New York, NY: Routledge Taylor \& Francois Group.

Ismaimuza, Dasa. (2010). Pengaruh pembelajaran berbasis masalah dengan strategi konflik kognitif terhadap kemampuan berpikir kritis matematis dan sikap siswa SMP. Journal Program Pascasarjana Universitas Pendidikan Ganesha program studi pendidikan matematika. Volume 4.1-10.

Ennis, R.H. (1996). Critical thinking disposition: their nature and assessability. Informal Logic, 18, 165-182.

Gerungan, W.A. (2004). Psikologi sosial. Bandung: PT. Refika Aditama.

Hassoubah, Z.I. (2007). Mengasah pikiran kreatif dan kritis: disertai ilustrasi dan latihan. Bandung: Nuansa.

Kemp, E.J., Morrison G.R.,\& Ross, S.M. (1994). Designing effective instruction. New York, NY: Merrill.

Mardapi, Djemari. (2008). Teknik penyusunan instrument tes dan non tes. Yogyakarta: Mitra Cendekia Offset.

Murwantono \& Sukidjo. (2015). Peningkatan hasil belajar IPS dengan model problem based learning berbantuan media simultan gambar. Harmoni sosial, Jurnal PIPS. Vol. 2. 1-13.

Nelson, J.L., Palonsky, S.B \& McCarthy, M. R. (2004). Critical issues in education dialogues and dialectics. New York, NY: McGraw Hill Companies, Inc.

Sanjaya, Wina. (2009). Strategi pembelajaran berorientasi standar proses pendidikan. Jakarta: Kencana Prenada Media Group. 
Sukardi. (2011). Evaluasi pendidikan: prinsip dan operasionalnya. Jakarta: Bumi Aksara.

Sulaiman, F, \& Eldy, E.F. (2014). A comparison of integrated problembased learning approach in theoretical and mathematical courses in physics towards students' critical thinking: a case study in University Malaysia Sabah. International Journal of Education and Research. 2. 1-10.

Suprihatiningrum, Jamil. (2013). Strategi pembelajaran teori \& aplikasi. Yogyakarta: Ar-Ruzz Media

Surapranata, S. (2006). Analisis, validitas, reliabilitas dan interpretasi hasil tes implementasi kurikulum 2004. Bandung: Remaja Rosdakarya.

Taufik, A.M. (2009). Inovasi pendidikan melalui problem based learning: bagaimana pendidik memberdayakan pemelajar di era pengetahuan. Jakarta: Kencana Prenada Media Group.

Trianto. (2009). Mendesain model pembelajaran inovatif-progresif. Jakarta: kencana.

Westwood, P.S. (2008). What teacher need to know about teaching methods. Camberwell, V: Acer Press.

Wood, E.J. (2004). Problem based learning: eksploiting knowledge of how people learn to promote effective learning. BEE-j Vol 3 di ambil pada tanggal 15 februari 2015, dari http:/bio.itsn.ac.uk/journal/volume 3/beej-3-5.htm. 